AKUNTABILITAS

Vol. VII No. 2, Agustus 2014

P-ISSN: $1979-858 \mathrm{X}$

Halaman $123-131$

\title{
FAKTOR-FAKTOR KEUANGAN YANG MEMPENGARUHI MARKET SHARE PERBANKAN SYARIAH DI INDONESIA
}

\author{
Bambang Saputra \\ STIE MADANI Balikpapan
}

\begin{abstract}
This Study aims to formulate the strategy of market share growth for islamic bangking is need to examine how much the effect of each independent variable is ROA, CAR, $F D R$, NPF, and REO on the dependent variable (Market Share) on Islamic Banking in Indonesia. The research was conducted on Islamic Banking in Indonesia, BUS and UUS using financial statement data are monthly basis for 36 months, starting in January 2010-December 2012. The method of analysis in this study is the analysis Descriptive Statistics and Simple Linear Regression Analysis. The test results suggest that, first, ROA has a positive significant effect on Market Share. Second, CAR has a positive significant effect on Market Share. Third, FDR had a positive significant effect on Market Share. Fourth, NPF has a significant negative effect on Market Share. Fifth, REO has a significant negative effect on Market Share. Based that condition, so, strategy to improve market share growth for Islamic banking must be concern to qualitative aspects such as sufficient costumer service, product innovative, banking education for costumer, etc. All of that aspects must be supported by government, central bank, Islamic banking, and society.
\end{abstract}

Keywords: Market Share, ROA, CAR, FDR, NPF, REO.

ABSTRAK: Penelitian ini bertujuan untuk merumuskan strategi pertumbuhan pangsa pasar perbankan syariah yang diperlukan untuk memeriksa berapa besar pengaruh masingmasing variabel independen adalah ROA, CAR, FDR, NPF, dan REO pada variabel dependen (Market Share) pada Bank Syariah di Indonesia. Penelitian ini dilakukan pada Bank Syariah di Indonesia, BUS dan UUS menggunakan data laporan keuangan secara bulanan selama 36 bulan, mulai bulan Januari 2010-Desember 2012. Metode analisis dalam penelitian ini adalah analisis deskriptif Statistik dan Sederhana Analisis Regresi Linier. Hasil tes menunjukkan bahwa, pertama, ROA memiliki pengaruh yang signifikan positif terhadap Pangsa Pasar. Kedua, CAR berpengaruh signifikan positif terhadap Pangsa Pasar. Ketiga, FDR memiliki efek yang signifikan positif terhadap Pangsa Pasar. Keempat, NPF memiliki efek negatif yang signifikan pada Market Share. Kelima, REO memiliki efek negatif yang signifikan pada Market Share.

Kata kunci: Pangsa Pasar, ROA, CAR, FDR, NPF, REO.

\footnotetext{
Draft pertama: 25 Maret 2014 Revisi: 17 April 2014: Diterima: 22 Mei 2014

*Penulis dapat dikontak melalui: poetracc@yahoo.co.id
} 


\section{PENDAHULUAN}

Industri perbankan syariah merupakan bagian dari sistem perbankan nasional yang mempunyai peranan penting dalam perekonomian. Peranan perbankan syariah secara khusus antara lain sebagai perekat nasionalisme baru, artinya menjadi fasilitator jaringan usaha ekonomi kerakyatan, memberdayakan ekonomi umat, mendorong penurunan spekulasi di pasar keuangan, mendorong pemerataan pendapatan, dan peningkatan efisiensi mobilitas dana.

Mengingat begitu pentingnya fungsi dan peranan perbankan syariah di Indonesia, maka pihak bank syariah perlu meningkatkan kinerjanya agar tercipta perbankan dengan prinsip syariah yang sehat, efektif dan efisien. Market Share Ratio dapat digunakan untuk mengukur kinerja bank syariah yang terbilang baru di Indonesia. Semakin besar market share bank syariah di Indonesia, semakin besar pula peran dan fungsinya bagi perekonomian nasional. Berdasarkan Outlook Perbankan Syariah 2013, market share perkembangan perbankan syariah di Indonesia sampai dengan bulan Desember 2012 tercatat sebesar $\pm 4,3 \%$.

Untuk mendukung peningkatkan market share tersebut dibutuhkan juga kinerja masing-masing bank syariah baik berbentuk BUS (Bank Umum Syariah) maupun UUS (Unit Usaha Syariah). Kinerja bank syariah sebagaimana layaknya sebuah perusahaan dapat dilihat dengan menganalisa laporan keuangan bank syariah. Metode CAMELS (Capital, Assets, Management, Earning, Likuidity, dan Sensitivity to Market Risk) dapat digunakan untuk menganalisa kinerja bank syariah dan kemudian dinilai kesehatan bank syariah. Beberapa rasio keuangan yang dapat mewakili CAMELS adalah Return on Total Assets (ROA), Capital Adequacy Ratio (CAR), Financing to Deposit Ratio (FDR), Non Performing Financing (NPF), dan Rasio Efisiensi Operasional (REO). Analisa kinerja keuangan tersebut yang mencerminkan tingkat kesehatan bank syariah diharapkan dapat berkontribusi terhadap peningkatan market share perbankan syariah di Indonesia.

ROA merupakan rasio antara laba sesudah pajak terhadap total asset. ROA yang merupakan indikator profitabilitas dijadikan variabel yang mempengaruhi market share. ROA digunakan untuk mengukur profitabilitas bank karena Bank Indonesia sebagai pembina dan pengawas perbankan lebih mengutamakan nilai profitabilitas suatu bank yang diukur dengan aset yang dananya sebagian besar dari dana simpanan masyarakat. Apabila profitabilitas suatu bank tersebut memiliki peningkatan yang signifikan maka masyarakat akan mempercayakan untuk menempatkan dananya di bank tersebut karena masyarakat akan memperhitungkan bagi hasil yang diperolehnya akan cukup menguntungkan baginya, oleh karena itu semakin besar ROA suatu bank, semakin besar pula tingkat keuntungan yang dicapai bank, dan semakin baik kinerja dan posisi market share bank tersebut.

Capital Adequacy Ratio (CAR) yang merupakan indikator permodalan dijadikan variabel yang mempengaruhi market share, didasarkan hubungannya dengan tingkat risiko bank. Kecukupan modal berkaitan dengan penyediaan modal sendiri yang diperlukan untuk menutup risiko kerugian yang mungkin timbul dari pergerakan aktiva bank yang pada dasarnya sebagian besar dana berasal dari dana pihak ketiga atau masyarakat. Tingginya rasio modal dapat melindungi deposan, dan meningkatkan kepercayaan masyarakat pada bank, dan akhirnya dapat meningkatkan market share. Manajemen bank perlu meningkatkan nilai CAR sesuai dengan ketentuan Bank Indonesia minimal delapan persen karena dengan modal yang cukup, bank dapat melakukan ekspansi usaha dengan lebih aman dalam rangka meningkatkan market share-nya.

Rasio likuiditas yang diproksikan dengan FDR dijadikan variabel yang mempengaruhi market share. Jika rasio ini meningkat dalam batas tertentu maka akan semakin banyak dana yang disalurkan dalam bentuk pembiayaan, sehingga akan meningkatkan market share bank syariah, dengan asumsi bank menyalurkan dananya untuk pembiayaan yang efektif. Dengan meningkatnya pembiayaan, masyarakat akan 
semakin mempercayakan untuk menyimpan dananya di bank syariah karena mereka sangat mengetahui dengan jelas bahwa dana yang mereka simpan dikelola dengan baik oleh bank syariah untuk disalurkan ke nasabah pembiayaan.

Kualitas Aktiva dalam hal ini diproksikan dengan NPF dijadikan variabel yang mempengaruhi market share karena mencerminkan risiko pembiayaan. Semakin tinggi rasio ini, menunjukkan kualitas pembiayaan bank syariah semakin buruk. Tingkat kesehatan pembiayaan (NPF) ikut mempengaruhi pencapaian pangsa pasar suatu bank. Nasabah akan merasa aman dalam menempatkan dananya di suatu bank karena dikelola dengan baik. Pengelolaan pembiayaan sangat diperlukan oleh bank, karena fungsi pembiayaan sebagai sumber pendapatan terbesar bagi bank syariah.

REO dijadikan variabel yang mempengaruhi market share karena REO tersebut mencerminkan operasional suatu bank. Apabila REO mengalami penurunan maka bank tersebut dinyatakan efisien dalam hal operasionalnya dan sebaliknya, apabila REO mengalami peningkatan maka bank tersebut dinyatakan tidak efisien. Sehingga mengakibatkan bank meningkatkan nisbah, margin, atau bagi hasil untuk meningkatkan pendapatannya dan akan menimbulkan risiko yang dapat mengurangi pangsa pasar bank syariah tersebut.

Penelitian ini dilakukan untuk menguji faktor-faktor keungan yang mempengaruhi market share perbankan syariah di Indonesia selama Januari 2010-Desember 2012. Faktorfaktor yang mempengaruhi market share dilihat melalui kinerja keuangan bank syariah seperti Return on Total Assets (ROA), Capital Adequacy Ratio (CAR), Financing to Deposit Ratio (FDR), Non Performing Financing (NPF), dan Rasio Efisiensi Operasional (REO).

\section{KERANGKA TEORI DAN PENGEMBANGAN HIPOTESIS}

Bank Islam atau yang disebut dengan Bank Syariah adalah bank yang beroperasi dengan tidak mengandalkan pada bunga. Bank syariah merupakan lembaga keuangan perbankan yang operasional dan produknya dikembangkan berlandaskan pada Al-Qur'an dan Hadist Nabi saw. Dengan kata lain Bank Umum Syariah adalah bank yang melakukan kegiatan usaha atau beroperasi berdasarkan prinsip syariah dan tidak mengandalkan pada bunga dalam memberikan pembiayaan dan jasa-jasa lainnya dalam lalu lintas pembayaran.

Adapun fungsi dari bank syariah antara lain sebagai berikut: (1) Manajer Investasi; (2) Investor; (3) Jasa Keuangan; dan (4) Fungsi Sosial. Setiap lembaga keuangan syariah mempunyai falsafah mencari keridhoan Allah untuk memperoleh kebajikan di dunia dan di akhirat. Oleh karena itu setiap kegiatan lembaga keuangan syariah harus menghindari (1) Menjauhkan diri dari unsur riba; dan (2) Menerapkan sistem bagi hasil dan perdagangan.

\section{Laporan Keuangan Bank Syariah}

Menurut ketentuan pemerintah, kegiatan usaha suatu bank harus dinyatakan dalam laporan keuangan yang diterbitkan dan dilaporkannya kepada masyarakat dan otoritas moneter sebagai pengawas perbankan nasional. Laporan keuangan bank syariah meliputi neraca, laporan laba rugi, laporan arus kas, laporan perubahan ekuitas, catatan atas laporan keuangan, laporan perubahan dana investasi terkait, laporan sumber dan penggunaan dana ZIS, laporan sumber dan penggunaan dana qardhul hasan.

Laporan keuangan bank menunjukkan kondisi bank secara keseluruhan. Laporan keuangan yang dihasilkan bank diharapkan dapat memberikan informasi tentang kinerja keuangan dan pertanggungjawaban manajemen bank kepada seluruh stake holder bank. Laporan keuangan digunakan untuk memenuhi kepentingan berbagai pihak. Di mana masing-masing pihak mempunyai tujuan sendiri-sendiri untuk mengetahui hasil interprestasi dari laporan keuangan tersebut (Kasmir, 2007:239).

Adapun pihak-pihak yang memiliki kepentingan terhadap laporan keuangan bank (Kasmir, 2007: 241) antara lain: 
a. Bagi pemegang saham, laporan keuangan bank digunakan untuk mengetahui kemajuan bank yang dikelola oleh manajemen dalam suatu periode kemajuan bank dapat dilihat dalam menciptakan laba, pengembangan aset dan usaha, serta dapat memberikan gambaran tentang jumlah deviden yang akan diterima.

b. Bagi pemerintah, laporan keuangan digunakan untuk mengetahui kepatuhan bank dalam melaksanakan kebijakan moneter yang telah ditetapkan, dan peranan perbankan dalam pengembangan sektor industri.

c. Laporan keuangan bagi manajemen digunakan untuk menilai kinerja manajemen bank dalam mencapai target yang telah ditetapkan dan kinerja manajemen bank dalam mengelola sumber daya yang dimilikinnya. Ukuran keberhasilan bank dapat dilihat dari pertumbuhan laba yang diperoleh dari pengembangan aset yang dimiliki. Selain itu, laporan keuangan ini dapat digunakan sebagai penilaian pemilik untuk memberikan kompensasi dan kepercayaan kepada pihak manajemen bank untuk mengelola bank pada periode berikutnya.

d. Bagi karyawan, melalui laporan keuangan dapat mengetahui kondisi keuangan bank yang sebenarnya. Dengan demikian karyawan dapat memahami kinerja mereka, sehingga jika bank mengalami keuntungan, maka dapat diharapkan ada peningkatan kesejahteraan, tetapi jika bank mengalami kerugian maka karyawan perlu melakukan perbaikan.

e. Bagi masyarakat, laporan keuangan dapat digunakan sebagai suatu jaminan terhadap uangnya yang disimpan di bank. Kepercayaan masyarakat untuk menyimpan dana tergantung dengan kondisi bank yang bersangkutan.

\section{Rasio Keuangan Bank Syariah}

Informasi akuntansi dalam bentuk laporan keuangan memberikan manfaat kepada pengguna apabila laporan keuangan tersebut dianalisa lebih lanjut sebelum dimanfaatkan sebagai alat bantu dalam pengambilan keputusan. Analisa laporan keuangan meliputi perhitungan dan interprestasi rasio keuangan. Analisa rasio keuangan dapat membantu para pemakai laporan keuangan dalam menilai kinerja keuangan suatu perusahaan atas kegiatan operasional yang dilakukan (Rahma Dewi, 2010).

Manajemen adalah faktor utama yang mempengaruhi profitabilitas bank. Seluruh manajemen bank, baik yang mencakup manajemen permodalan, manajemen kualitas aktiva, manajemen umum, manajemen likuiditas dan rentabilitas pada akhirnya akan mempengaruhi dan bermuara pada perolehan laba (profitabilitas) pada perusahaan. Demikian juga kinerja manajeman bank syariah yang mencakup manajeman permodalan, likuiditas, efisiensi, aktiva produktif dan rentabilitas pada akhirnya akan mempengaruhi efektifitas dan efisiensi suatu bank syariah yang dinyatakan dengan Market Share.

Penelitian mengenai rasio keuangan bank di Indonesia telah dilakukan oleh beberapa peneliti. Dalam penelitian terdahulu ini dicantumkan beberapa penelitian rasio keuangan yang berpengaruh pada Return on Asset (ROA) dikarenakan pada saat Bank Syariah mengalami peningkatan pada profitabilitasnya yang akan berpengaruh pada peningkatan asset yang diukur dalam Market Share (MS). Selain karena hal tersebut, penyebab lainnya yaitu karena penelitian yang menggunakan MS sebagai variabel dependennya masih jarang dilakukan. Adapun penelitian terdahulu yang berkaitan dengan penelitian ini antara lain:

Penelitian Setiawan (2009), mengalisis pengaruh faktor makroekonomi, pangsa pasar dan karakteristik bank terhadap profitabilitas bank syariah (studi pada bank syariah periode 2005-2008). Tujuan penelitian adalah untuk menganalisis pengaruh kondisi ekonomi makro yang diproksi dengan inflasi dan GDP, pengaruh karakteristik bank yang diproksi dari FDR, CAR, NPF, BOPO dan SIZE, dan pengaruh pangsa pasar yang diproksi dengan pembiayaan bank syariah terhadap profitabilitas bank syariah yang diproksikan 
dengan ROA. Hasil penelitian menunjukkan bahwa variabel inflasi dan GDP, tidak berpengaruh terhadap ROA. pangsa pembiayaan, CAR, FDR berpengaruh signifikan positif terhadap ROA perbankan, sedangkan BOPO, NPF, dan SIZE berpengaruh signifikan negatif terhadap ROA Bank Syariah.

Penelitian Ponco (2008), menganalisa pengaruh CAR, NPL, BOPO, NIM, LDR terhadap ROA pada perusahaan perbankan yang terdaftar di BEI tahun 2004-2007. Hasil penelitian menunjukkan bahwa variabel CAR, NIM, LDR berpengaruh signifikan positif terhadap ROA perbankan, sedangkan BOPO berpengaruh signifikan negatif terhadap ROA perbankan, dan NPL tidak berpengaruh signifikan terhadap ROA perbankan.

Dhika Rahma Dewi (2010), menganalisa pengaruh CAR, FDR, NPF REO terhadap ROA pada perbankan syariah (bank muamalat, bank syariah mandiri, dan bank mega syariah) dengan data laporan keuangan periode triwulan terakhir dari tahun 2005-2008. Hasil penelitian menunjukkan bahwa variabel CAR, FDR berpengaruh signifikan positif terhadap ROA perbankan, sedangkan REO berpengaruh signifikan negatif terhadap ROA perbankan, dan NPF tidak berpengaruh signifikan terhadap ROA perbankan.

Berdasarkan kerangka teoritis dan penelitian terdahulu, maka dirumuskan hipotesis penelitian sebagai berikut:

$\mathbf{H}_{\mathbf{1}}$ : $\quad$ ROA berpengaruh signifikan positif terhadap market share perbangkan syariah.

$\mathbf{H}_{2:} \quad$ CAR berpengaruh signifikan positif terhadap market share perbangkan syariah.

$\mathbf{H}_{3}$ : $\quad$ FDR berpengaruh signifikan positif terhadap market share perbangkan syariah.

$\mathbf{H}_{4}$ : NPF berpengaruh signifikan negatif terhadap market share perbangkan syariah.

$\mathbf{H}_{5}:$ REO berpengaruh signifikan positif terhadap market share perbangkan syariah.

\section{METODE PENELITIAN}

Jenis penelitian ini merupakan penelitian empiris dengan hypotheses testing, yang bertujuan menguji model hipotetik. Data penelitian yang digunakan berupa data sekunder yang bersifat historis yaitu laporan keuangan bulanan yang telah dilaporkan ke Bank Indonesia periode bulanan dari Januari 2010-Desember 2012. Sumber penunjang lainnya berupa jurnal yang diperlukan, dan sumber-sumber lain yang dapat digunakan dalam penelitian ini.

Metode pengumpulan data yang digunakan yaitu melalui studi pustaka dari Direktori Perbankan Indonesia dan situs www.bi.go.id. Serta mengkaji buku-buku, jurnal dan majalah untuk memperoleh landasan teoritis yang komprehensif tentang bank syariah, media cetak, serta mengeksplorasi laporan-laporan keuangan dari bank berupa laporan neraca, laporan laba rugi dan kualitas aktiva produktif.

Populasi dalam penelitian ini adalah bank syariah yang terdaftar di Bank Indonesia pada Januari 2010-Desember 2012. Sampel penelitian diambil secara purposive sampling (non probability sampling) yaitu pemilihan sampel pada karakteristik populasi yang sudah diketahui sebelumnya dengan kriteria sebagai berikut:

a. Bank syariah merupakan Bank Umum Syariah (BUS) dan Unit Usaha Syariah (UUS).

b. Bank Syariah tersebut membuat laporan keuangan bulanan pada periode Januari 2010Desember 2012 dan telah dipublikasikan di Bank Indonesia.

c. Data yang dibutuhkan untuk penelitian tersedia selama periode Januari 2010Desember2012.

Metode analisis yang digunakan dalam penelitian ini adalah analisis regresi, dengan model umum dijelaskan dengan gambar sebagai berikut: 


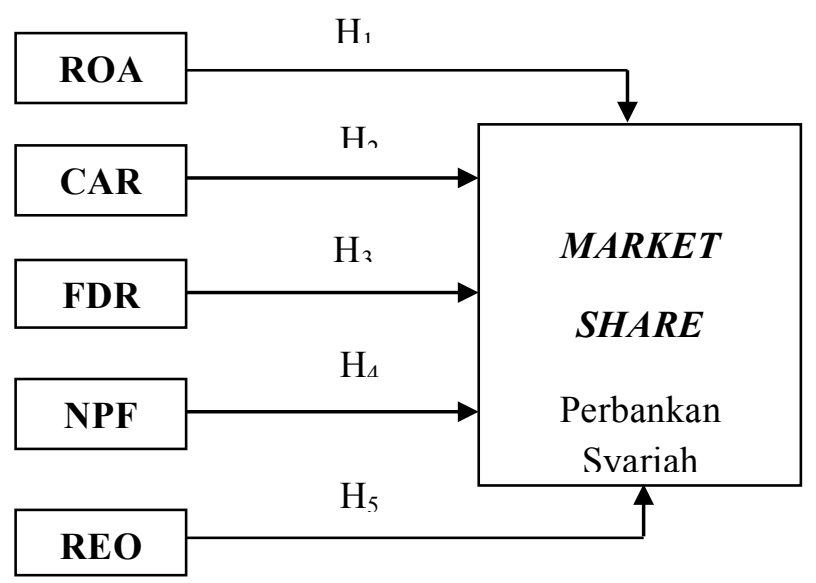

Gambar 1. Model Penelitian

\section{HASIL DAN PEMBAHASAN}

Hasil uji statistik deskriptif variabel dependen dan independen akan dijelaskan dalam tabel 1 berikut dibawah ini:

Tabel 1. Statistik Deskriptif Variabel Dependen dan Independen

\begin{tabular}{|l|c|c|c|c|c|}
\hline & $\mathrm{N}$ & Minimum & Maximum & Mean & Std. Deviation \\
\hline MS & 36 & .0260 & .0440 & .033778 & .0051276 \\
ROA & 36 & .0130 & .0230 & .018611 & .0020463 \\
CAR & 36 & .1110 & .2020 & .151722 & .0209988 \\
FDR & 36 & .8710 & 1.0210 & .951722 & .0391573 \\
NPF & 36 & .0220 & .0480 & .034361 & .0071280 \\
REO & 36 & .7480 & .8620 & .783417 & .0273019 \\
Valid N (listwise) & 36 & & & & \\
\hline
\end{tabular}

Sumber: Hasil Pengolahan Data, 2013

Berdasarkan tabel 1, dapat dijelaskan beberapa hal sebagai berikut:

1. Market share terendah (minimum) sebesar 2,60\% dan tertinggi (maksimum) sebesar 4,40\% sementara standar deviasinya sebesar $0,51 \%$ lebih kecil dibandingkan dengan nilai rata-rata (mean) sebesar 3,38\%. Dengan demikian dapat dikatakan bahwa simpangan data pada rasio MS relatif baik.

2. ROA terendah (minimum) sebesar $1,30 \%$ dan tertinggi (maksimum) sebesar $2,30 \%$ sementara standar deviasinya $(\sigma)$ sebesar $0,20 \%$ lebih kecil dibandingkan dengan nilai rata-rata (mean) sebesar $1,86 \%$. Hal tersebut menunjukkan bahwa secara statistik, selama periode penelitian besarnya ROA Perbankan Syariah di Indonesia sudah memenuhi standar yang ditetapkan Bank Indonesia, yaitu di atas 1,5\%. Dengan demikian dapat dikatakan bahwa simpangan data pada rasio ROA relatif baik.

3. CAR nilai terendah (minimum) sebesar $11,10 \%$ dan nilai tertinggi (maksimum) sebesar 20,20\% sementara nilai rata-rata (mean) sebesar 15,17\% lebih besar dibandingkan standar deviasi sebesar $\mathbf{2 , 1 0} \%$. Hal ini menunjukkan bahwa selama periode penelitian, secara statistik dapat dijelaskan bahwa tingkat perolehan modal Perbankan Syariah sudah memenuhi standar yang ditetapkan Bank Indonesia yaitu minimal 8\%. Sehingga dapat disimpulkan rasio kecukupan modal yang dimiliki Perbankan Syariah dapat 
dikatakan tinggi. Dengan demikian dapat dikatakan bahwa simpangan data pada CAR relatif baik.

4. FDR terendah (minimum) sebesar $87,10 \%$ dan tertinggi (maksimum) sebesar $102,10 \%$ sementara standar deviasinya $(\sigma)$ sebesar 3,92\% lebih kecil dibandingkan dengan nilai rata-rata (mean) sebesar 95,17\%. Secara statistik, dengan rata-rata 95,17\%, dapat disimpulkan bahwa FDR yang dicapai Perbankan Syariah berada dikisaran standar yang ditetapkan Bank Indonesia yaitu 85\%-100\%. Hal tersebut menunjukkan bahwa secara statistik, selama periode penelitian besarnya FDR Perbankan Syariah di Indonesia telah memenuhi standar yang ditetapkan Bank Indonesia. Dalam hal ini simpangan data dikatakan baik, karena nilai standar deviasinya lebih kecil daripada nilai mean-nya.

5. NPF diperoleh nilai rata-rata (mean) sebesar $2,20 \%$ dengan nilai terendah (minimum) sebesar $0,40 \%$ dan tertinggi (maksimum) sebesar $4,80 \%$, sementara nilai rata-rata (mean) sebesar 3,44\% lebih besar dibanding standar deviasi sebesar 0,71\% Dapat disimpulkan bahwa secara statistik, selama periode penelitian, tingkat NPF Perbankan Syariah telah memenuhi standar yang ditetapkan BI, yaitu maksimal 5\%. Dengan demikian dapat dikatakan bahwa simpangan data NPF relatif baik.

6. REO terendah (minimum) sebesar $74,80 \%$ dan tertinggi (maksimum) sebesar $86,20 \%$ sementara standar deviasinya $(\sigma)$ sebesar $2,73 \%$ lebih kecil dibandingkan dengan nilai rata-rata (mean) sebesar 78,34\%. Dengan demikian dapat disimpulkan bahwa secara statistik, selama periode penelitian tingkat efisiensi operasi Perbankan Syariah di Indonesia masih cukup efisien, karena rata-rata rasio BOPO dibawah $80 \%$. Sementara untuk melihat berapa besar simpangan data pada rasio BOPO dilihat dari standart deviasinya yaitu sebesar 2,73\%. Dalam hal ini simpangan data bisa dikatakan baik, karena nilai standart deviasinya lebih kecil daripada nilai mean-nya.

Tabel 2. Hasil Analisa Regresi

\begin{tabular}{|c|c|c|c|c|c|}
\hline Variabel & $\begin{array}{c}\text { Koefisien } \\
\text { Regresi }\end{array}$ & $\begin{array}{l}\text { Standart } \\
\text { Error }\end{array}$ & $\begin{array}{c}\mathrm{t}- \\
\text { statistik }\end{array}$ & p-value & Keterangan \\
\hline $\mathrm{ROA} \rightarrow \mathrm{MS}$ & 0,866 & 0,403 & 2,147 & 0,039 & Signifikan ** \\
\hline $\mathrm{CAR} \rightarrow \mathrm{MS}$ & 0,077 & 0,040 & 1,938 & 0,061 & Signifikan * \\
\hline FDR $\rightarrow$ MS & 0,039 & 0,021 & 1,833 & 0,076 & Signifikan * \\
\hline $\mathrm{NPF} \rightarrow \mathrm{MS}$ & $-0,673$ & 0,043 & $-15,479$ & 0,000 & Signifikan *** \\
\hline $\mathrm{REO} \rightarrow \mathrm{MS}$ & $-0,095$ & 0,028 & $-3,410$ & 0,002 & Signifikan *** \\
\hline \multicolumn{6}{|c|}{$\begin{array}{l}\text { Ket: } \\
* * * \operatorname{Sig} \alpha=1 \%,{ }^{* *} \operatorname{Sig} \alpha=5 \%,{ }^{*} \operatorname{Sig} \alpha=10 \%\end{array}$} \\
\hline
\end{tabular}

Sumber: Hasil Pengolahan Data, 2013 berikut:

Berdasarkan hasil pengolahan data pada tabel 2 di atas diperoleh hasil sebagai

1. ROA berpengaruh signifikan positif $(0,866)$ terhadap $M S$ dan $H_{1}$ diterima. Hasil penelitian menunjukkan bahwa semakin besar ROA suatu bank maka semakin baik pula Market Share-nya. Apabila profitabilitas suatu bank tersebut memiliki peningkatan yang signifikan maka masyarakat akan mempercayakan untuk menempatkan dananya di bank tersebut karena masyarakat akan memperhitungkan bagi hasil yang diperoleh akan cukup menguntungkan baginya, oleh karena itu semakin besar ROA suatu bank, semakin besar pula tingkat keuntungan yang dicapai bank, dan semakin baik kinerja dan posisi pangsa pasar bank tersebut.

2. CAR berpengaruh signifikan positif $(0,077)$ terhadap $M S$ dan $\mathrm{H}_{2}$ diterima. Hasil penelitian ini menunjukkan bahwa semakin besar CAR maka MS yang dicapai bank syariah akan 
semakin besar, karena semakin besar CAR maka semakin tinggi kemampuan permodalan bank dalam menjaga kemungkinan timbulnya risiko kerugian kegiatan usahanya. Rendahnya CAR dikarenakan peningkatan ekspansi aset beresiko yang tidak diimbangi dengan penambahan modal menurunkan kesempatan bank untuk berinvestasi dan menurunkan kepercayaan masyarakat sehingga berpengaruh pada penurunan pangsa pasar. Tingginya rasio modal dapat melindungi deposan, dan memberikan dampak meningkatnya kepercayaan masyarakat kepada bank, yang pada akhirnya dapat meningkatkan market share.

3. FDR berpengaruh signifikan positif $(0,039)$ terhadap $M S$ dan $\mathrm{H}_{3}$ diterima. Hasil penelitian ini menunjukkan bahwa semakin tinggi FDR maka akan semakin tinggi MS. Semakin meningkatknya FDR bank syariah dalam batas tertentu, maka semakin meningkat pula laba bank yang pada akhirnya menimbulkan peningkatan pembiayaan dan mengakibatkan tingginya market share bank syariah, dengan asumsi bank menyalurkan dananya untuk pembiayaan yang efektif.

4. NPF berpengaruh signifikan negatif $(-0,673)$ terhadap $M S$ dan $H_{4}$ diterima. Hasil penelitian ini menunujukkan bahwa semakin banyaknya pembiayaan bermasalah membuat bank syariah tidak berani meningkatkan penyaluran pembiayaannya apalagi bila dana pihak ketiga tidak dapat dicapai secara optimal maka dapat mengganggu likuiditas suatu bank. Pengelolaan pembiayaan sangat diperlukan oleh bank, mengingat fungsi pembiayaan sebagai penyumbang pendapatan terbesar bagi bank syariah. Tingkat kesehatan pembiayaan (NPF) ikut mempengaruhi peningkatan pangsa pasar bank. Adanya pembiayaan bermasalah yang besar dapat mengakibatkan hilangnya kesempatan untuk memperoleh pendapatan dari pembiayaan yang diberikan sehingga berpengaruh buruk pada market share. Dengan demikian semakin besar NPF akan mengakibatkan menurunnya market share.

5. REO berpengaruh signifikan negatif $(-0,095)$ terhadap $M S$ dan $H_{5}$ diterima. Tingkat efisiensi bank dalam menjalankan operasinya, berpengaruh terhadap tingkat Market Share suatu bank. Apabila REO mengalami penurunan maka bank tersebut dinyatakan efisien dalam hal operasionalnya dan sebaliknya, apabila REO mengalami peningkatan maka bank tersebut dinyatakan tidak efisien. Sehingga mengakibatkan bank meningkatkan nisbah, margin, atau bagi hasil untuk meningkatkan pendapatannya dan akan menimbulkan resiko yang dapat mengurangi market share bank syariah.

\section{SIMPULAN}

Berdasarkan analisis data dan pembahasan yang telah disimpulkan bahwa Return On Asset (ROA), Capital Adequacy Ratio (CAR), Financing to Deposit Ratio (FDR) berpengaruh signifikan positif terhadap Market Share (MS) Perbankan Syariah di Indonesia. Sedangkan untuk Non Performing Financing (NPF) dan Rasio Efisiensi Operasi (REO) berpengaruh signifikan negatif terhadap Market Share (MS) Perbankan Syariah di Indonesia, sehingga menyebabkan seluruh hipotesis diterima. Hasil penelitian ini berimplikasi bahwa pihak manajemen perbankan syariah perlu menjaga kinerja dan kesehatan keuangannya, terutama meningkatkan ROA, CAR, FDR agar dapat meningkatkan MS serta menurunkan NPF dan REO. Dengan didukung pengawasan dan pembinaan dari Bank Indonesia dan Otoritas Jasa Keuanga (OJK) yang tepat serta pemilihan stratergi yang tepat pula untuk peningkatan kinerja dan kesehatan bank syariah, diharapkan dapat meningkatkan pertumbuhan market share perbankan syariah di Indonesia.

\section{PUSTAKA ACUAN}

Antonio, Muhammad S. 2001. Bank Syariah dari Teori ke Prakti. Jakarta: Gema Insani Press. 
Aristya, Diah H. 2010. Analisis Pengaruh Ukuran Perusahaan, Kecukupan Modal, Kualitas Aktiva Produktif (KAP), dan Likuiditas Terhadap Kinerja Keuangan (Studi Pada Bank Umum Syariah di Indonesia Periode 2005-2009). Skripsi. Semarang: Fakultas Ekonomi Universitas Diponegoro.

Bank Indonesia. 2012. Buletin Ekonomi Moneter dan Perbankan, Vol. 2 No. 3: edisi Desember 1999, diakses 28 Agustus 2012, dari http//:www.bi.go.id . 2012. Outlook Perbankan Syariah 2013, diakses 14 Juli 2012, dari http//:www.bi.go.id 2012. Statistik Perbankan Indonesia Januari 2010 - Desember 2012, diakses 23 Agustus 2012, dari http//:www.bi.go.id . 2012. Statistik Perbankan Syariah Januari 2010 - Desember 2012, diakses 23 Agustus 2012, dari http//:www.bi.go.id

Dendawijaya, Lukman. 2003. Manajemen Perbankan. Jakarta: Ghalia Indonesia.

Gozhali, Imam. 2007. Aplikasi Multivariate dengan Program SPSS. Semarang: Badan Penerbit Universitas Diponegoro.

Hasibuan, Melayu S.P. 2005. Dasar-Dasar Perbankan. Jakarta: Bumi Aksara.

Kasmir. 2007. Manajemen Perbankan. Jakarta: PT RajaGrafindo Persada.

Ponco, Budi. 2008. Analisis Pengaruh CAR, NPL, BOPO, NIM, dan LDR Terhadap ROA (Studi Kasus Pada Perusahaan Perbankan Yang Terdaftar di Bursa Efek Indonesia Periode 2004-2007). Tesis. Semarang: Program Pascasarjana Magister Manajemen Universitas Diponegoro.

Rahma, Dhika D. 2010. Faktor-Faktor Yang Mempengaruhi Profitabilitas Bank Syariah di Indonesia. Skripsi. Semarang: Fakultas Ekonomi Universitas Diponegoro.

Rivai, Viethzel, dan Idroes. 2007. Bank and Fianancial Instution Management. Jakarta: PT RajaGrafindo Persada.

Sinungan, Muchdarsyah. 200o. Manajemen Dana Bank. Jakarta: Bumi Aksara.

Stiawan, Adi. 2009. Analisis Pengaruh Faktor Makro Ekonomi, Pangsa Pasar, dan Karakteristik Bank Terhadap Profitabilitas Bank Syariah (Studi Pada Bank Syariah Periode 2005-2008). Tesis. Semarang: Program Pascasarjana Magister Manajemen Universitas Diponegoro.

Undang-Undang RI No. 10 Tahun 1998 tentang Perubahan atas Undang-Undang Nomor 7 Tahun 1992 tentang Perbankan.

Yuliani, 2007. Hubungan Efisiensi Operasional dengan Kinerja Profitabilitas Pada Sektor Perbankan Yang Go Public di Bursa Efek Jakarta. Jurnal Manajemen dan Bisnis Sriwijaya. Volume 5 . 